\title{
Theory of Additional Corpus Biopsy for Epidemiology and Diagnosis of Helicobacter Pylori
}

\author{
Vijay Kumar Bontha*, Swathi Goli ,Prasad Garrepally \\ Jangaon Institute of Pharmaceutical Sciences, Depot. Of Pharmaceutics, Jangaon, India. \\ *Corresponding Author: Vijay Kumar Bontha - Jangaon Institute of Pharmaceutical Sciences, Depot. Of Pharmaceutics, Jangaon, India. \\ Email-vijaypharmacy2000@gmail.com \\ Received date: December 01,2017;Accepted date : December 22,2018; Published date: December 26,2017. \\ Citation for this Article Vijay Kumar Bontha. Theory of Additional Corpus Biopsy for Epidemiology and Diagnosis of Helicobacter Pylori. J. \\ Gastroenterology Pancreatology and Hepatobilary Disorders. 1(1). Doi: 10.31579/2641-5194/003
}

Copyright : (c) 2017 Vijay Kumar Bontha. This isan open-access article distributed under the terms of the Creative Commons Attribution License, which permits unrestricted use, distribution, and reproduction in any medium, provided the original author and source are credited.

\begin{abstract}
Background

There isstilldebate onthebestsites for biopsy- based tests of Helicobacterpylori infection inpatients with gastritis. Thisstudy wasdesigned to determine if it is important to add corpus biopsies to the routine antral ones for identification of $\mathrm{H}$. pylori, especially in case of gastric atrophy and/or intestinalmetaplasia.

Methods

A causative role is nowaccepted for Helicobacter (formerly Campylobacter) pylori in type $\mathrm{B}$ gastritis, and evidence is accumulating that $\mathrm{H}$. pylori infection plays a major contributory role in peptic ulcer disease. Preliminary studies have reported that the prevalence of $\mathrm{H}$ pylori infection increases with age, butdetailed information on the prevalence of the bacteria inanydefinedpopulation andonthefactors that may influence the pattern of distribution remains scanty.
\end{abstract}

Results

Up to $85 \%$ of people infected with $\mathrm{H}$. pylori never experience symptoms or complications. Acute infection may appear as an acute gastritis with abdominal pain (stomach ache) or nausea. Where this develops into chronic gastritis, the symptoms, if present, are often those of nonulcer dyspepsia: stomach pains, nausea, bloating, belching, and sometimes vomiting or black stool.

Conclusion

H. pylori has been associated with colorectal polyps and colorectal cancer. It may also be associated with eye disease.

Key Words

gastric atrophy; sydney system; h. pylori; gastritis

\section{Introduction}

Helicobacter pylori affect nearly half of the population among the world. It is one of the most frequent and persistent bacterial infections worldwide [1]. It is responsible for many of the upper gastrointestinal tract diseases; chronic gastritis, gastrointestinal ulcers, Mucosa Associated Lymphoid Tissue Lymphoma (MALT) and gastric cancer as well [2]. Thus it has been known as "definitive biological carcinogen" by WHO in 1994 [3].

It is also linked to the development of duodenal ulcers and stomach cancer. However, over $80 \%$ of individuals infected with the bacterium are asymptomatic, and it may play an important role in the natural stomach ecology [4].

Up to $85 \%$ of people infected with $H$. pylori never experience symptoms or complications.[5] Acute infection may appear as an acute gastritis with abdominal pain (stomach ache) or nausea.[3] Where this develops into chronic gastritis, the symptoms, if present, are often those of nonulcer dyspepsia: stomach pains, nausea, bloating, belching, and sometimes vomiting or black stool.[6][7]

Individuals infected with $\mathrm{H}$. pylori have a 10 to $20 \%$ lifetime risk of developing peptic ulcers and a 1 to $2 \%$ risk of acquiring stomach cancer.[5][7] Inflammation of the pyloric antrum is more likely to lead to duodenal ulcers, while inflammation of the corpus (body of the stomach) is more likely to lead to gastric ulcers and gastric carcinoma. However, H. pylori possibly plays a role only in the first stage that leads to common chronic inflammation, but not in further stages leading to carcinogenesis.
A meta-analysis conducted in 2009 concluded the eradication of $\mathrm{H}$. pylori reduces gastric cancer risk in previously infected individuals, suggesting the continued presence of $\mathrm{H}$. pylori constitutes a relative risk factor of $65 \%$ for gastric cancers; in terms of absolute risk, the increase was from $1.1 \%$ to $1.7 \%$ This study was designed to determine if it is important to add corpus biopsies to the routine antral ones for identification of $H$. pylori, especially in case of gastric atrophy and/or intestinal metaplasia.

\section{Methods and Materials}

At least half the world's population is infected by the bacterium, making it the most widespread infection in the world. Actual infection rates vary from nation to nation; the developing world has much higher infection rates than the West (Western Europe, North America, Australasia), where rates are estimated to be around $25 \%$.

The age when someone acquires this bacterium seems to influence the pathologic outcome of the infection. People infected at an early age are likely to develop more intense inflammation that may be followed by atrophic gastritis with a higher subsequent risk of gastric ulcer, gastric cancer, or both. Acquisition at an older age brings different gastric changes more likely to lead to duodenal ulcer.[5] Infections are usually acquired in early childhood in all countries. However, the infection rate of children in developing nations is higher than in industrialized nations, probably due to poor sanitary conditions, perhaps combined with lower antibiotics usage for unrelated pathologies. 
In developed nations, it is currently uncommon to find infected children, but the percentage of infected people increases with age, with about $50 \%$ infected for those over the age of 60 compared with around $10 \%$ between 18 and 30 years. The higher prevalence among the elderly reflects higher infection rates in the past when the individuals were children rather than more recent infection at a later age of the individual. In the United States, prevalence appears higher in AfricanAmerican and Hispanic populations, most likely due to socioeconomic factors. The lower rate of infection in the West is largely attributed to higher hygiene standards and widespread use of antibiotics. Despite high rates of infection in certain areas of the world, the overall frequency of $\mathrm{H}$. pylori infection is declining. However, antibiotic resistance is appearing in $\mathrm{H}$. pylori; many metronidazole- and clarithromycin-resistant strains are found in most parts of the world.

\section{Patients}

Three hundred and twenty eight consecutive patients of uninvestigated dyspepsia, who underwent upper endoscopy were enrolled, (Mansura university hospital - Egypt, Benha University hospital - Egypt, Hafer Albatin Central Hospital, KSA) from June 2014 to December 2015. Patients who received antibiotic or proton pump inhibitor treatment one month before hand were excluded. All procedures in the study were performed in accordance with the institutional research board (IRB) committee in our institute.

\section{Study Protocol}

All patients underwent upper gastrointestinal endoscopy and two standard gastric biopsies were taken from both antrum $(2-3 \mathrm{~cm}$ from the pylorus both lesser and greater curvature) and corpus $(8-10 \mathrm{~cm}$ from the cardia both lesser and greater curvature) for the histological examination [15].

\section{Histological Examination}

Endoscopic biopsies were processed as formalin fixed paraffin embedded tissues, cut into $3 \mu \mathrm{m}$ thick sections, and then stained with H\&E and modified Giemsa stain. These were scored semiquantitatively according to the updated Sydney classification [15] (Figure 1). The following features were evaluated on each slide, inflammatory activity, glandular atrophy and intestinal metaplasia. According to these histological criteria, there were four grades of atrophy; 0- none; 1- mild; 2- moderate and 3- severe.
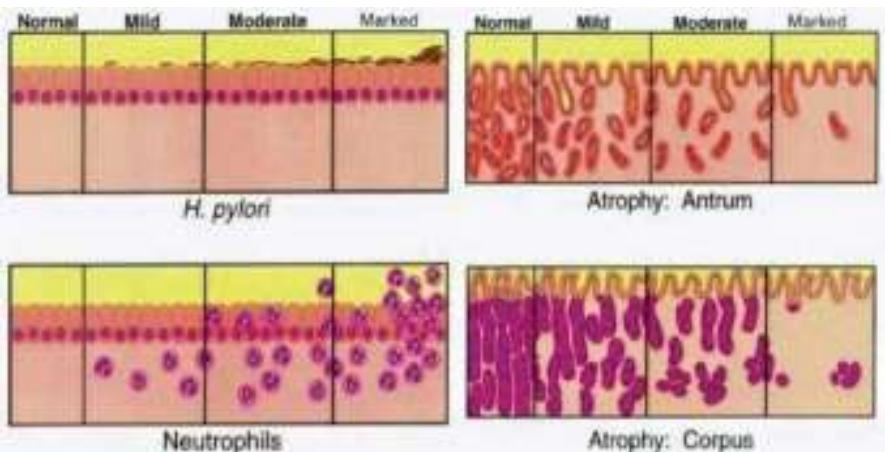

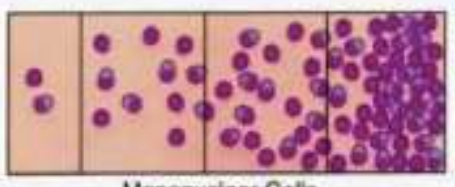

Mononuclear Cells

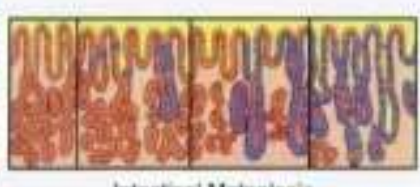

Intestinal Metaplasia
Figure 1: Sydney classification for gastric biopsy.

Criteria for positivity and negativity of $H$. pylori were set: Patients were defined positive for $H$. pylori if either one or both was positive with Giemsa stained slides. Patients were considered negative if all specimens were negative. The histological evidence of atrophy was identified when the gastric glands were found decreased in amount and/or widely separated [16].

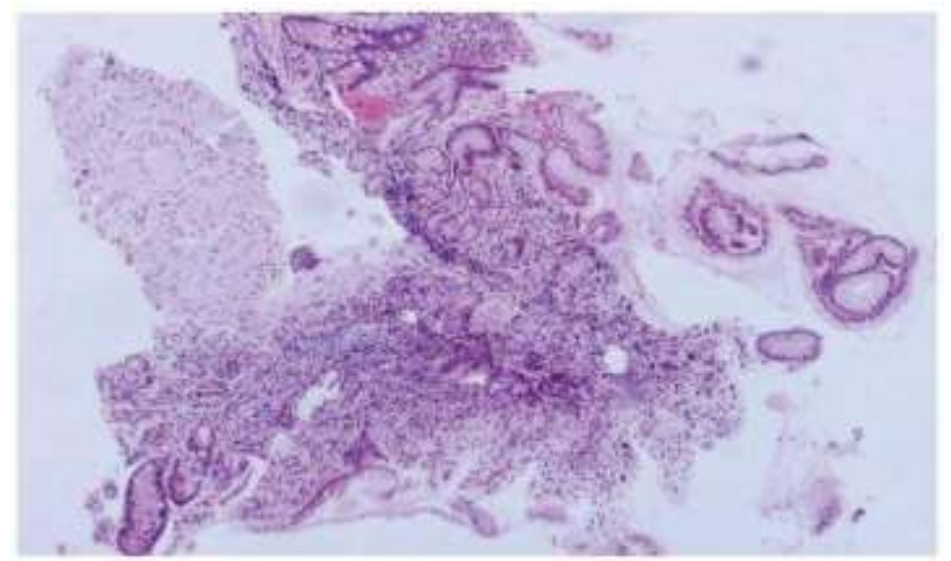

Figure 2: Gastric biopsy showed marked gastric atrophy (H\&E X100).

\section{Results}
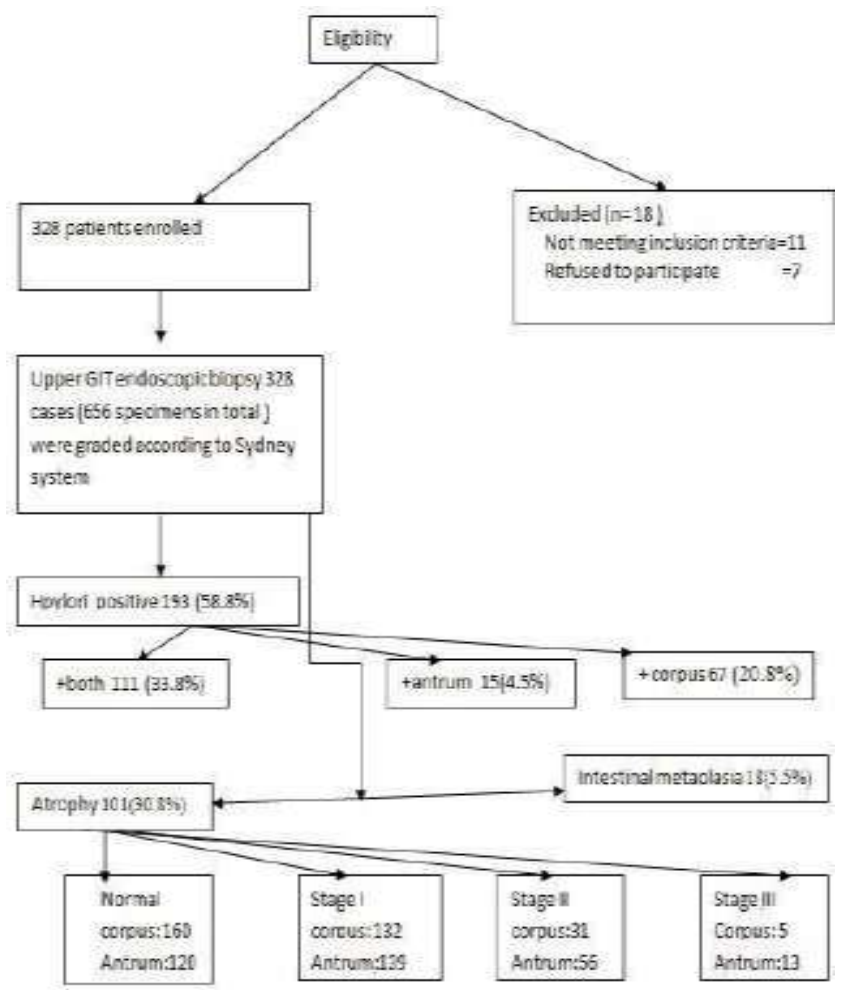

Figure 3: Patients' flowchart.

Figure 3 shows the flow chart for the whole study population. A total of 328 consecutive patients underwent an upper endoscopy procedure during the study period. The mean age of our patients was $39 \pm 12$ years; 145 $(44.3 \%)$ were men. Upper gastrointestinal endoscopy was indicated for functional dyspepsia in $113(34.5 \%)$, epigastric pain in118 (35.9\%) or heart burn in 97 (29.6\%) patients. Endoscopic diagnosis was peptic ulcer disease in $52(15.9 \%)$, gastritis or duodenitis in $173(52.7 \%)$, or reflux esophagitis in $103(31.4 \%)$ patients. None of our patients were diagnosed with gastric carcinoma. Regardless of the biopsy site, a total of 656 biopsy specimens were received for histological evaluation (Table 1).

In endoscopic diagnosis, atrophy was found in 101 (30.8\%) of our patients. Atrophic gastritis was significantly more often in the antrum than the corpus (29.2 vs $11.9 \%$, respectively, $p<0.05)$. Intestinal metaplasia was identified in $17(5.2 \%)$ patients and antrum was more often than the corpus ( 4 vs $2 \%$ of all patients, respectively). Patients with only positive corpus biopsies showed more incidences of both atrophy and intestinal metaplasia compared with the other possible outcomes, 55 vs $24.5 \%$ for atrophy and 10 vs $4.6 \%$ for metaplasia (Table 1,2 ). 
J Gastroenterology Pancreatology and Hepatobilary Disorders

\begin{tabular}{|c|c|c|c|c|c|}
\hline Variables & $\mathrm{N}=328$ & Both +ve & both -ve & $C+$ ve only & A +ve only \\
\hline $\begin{array}{l}\text { Gender } \\
\text {-Male } \\
\text {-Female }\end{array}$ & $\begin{array}{l}215 \\
113 \\
\end{array}$ & $\begin{array}{l}63 \% \\
37 \% \\
\end{array}$ & $\begin{array}{l}58 \% \\
42 \% \\
\end{array}$ & $\begin{array}{l}62 \% \\
38 \% \\
\end{array}$ & $\begin{array}{l}47 \% \\
53 \% \\
\end{array}$ \\
\hline Age in years & $31 \pm 9$ & $32 \pm 8$ & $27 \pm 6$ & $33 \pm 7$ & $34 \pm 9.5$ \\
\hline $\begin{array}{l}\text { Endoscopic diagnosis } \\
\text {-Peptic ulcer } \\
\text {-Gastritis/duodenitis } \\
\text {-GERD } \\
\text {-Normal }\end{array}$ & $\begin{array}{c}87 \\
101 \\
63 \\
11 \%\end{array}$ & $\begin{array}{l}33 \% \\
27 \% \\
29 \% \\
13 \% \\
\end{array}$ & $\begin{array}{l}24 \% \\
29 \% \\
18 \% \\
21 \% \\
\end{array}$ & $\begin{array}{l}26 \% \\
22 \% \\
31 \% \\
31 \%\end{array}$ & $\begin{array}{l}29 \% \\
16 \% \\
24 \% \\
31 \%\end{array}$ \\
\hline $\begin{array}{l}\text { Microscopic findings } \\
\text {-Atrophy } \\
\text { Corpus and antrum } \\
\text { Antrum only } \\
\text { Corpus only }\end{array}$ & $\begin{array}{c}101(30.8 \%) \\
34 \\
62 \\
5\end{array}$ & $\begin{array}{c}43(38.7 \%) \\
19 \\
24 \\
-\end{array}$ & $\begin{array}{c}19(14 \%) \\
- \\
15 \\
4\end{array}$ & $\begin{array}{c}2(13 \%) \\
- \\
- \\
-\end{array}$ & $\begin{array}{c}37(55 \%) \\
13 \\
23 \\
1 \\
\end{array}$ \\
\hline $\begin{array}{l}\text {-Intestinal metaplasia } \\
\text { Corpus and antrum } \\
\text { Antrum only } \\
\text { Corpus only }\end{array}$ & $\begin{array}{c}18(5.5 \%) \\
3 \\
11 \\
4\end{array}$ & $\begin{array}{c}6(5.4 \%) \\
5 \\
5 \\
1\end{array}$ & $\begin{array}{c}5(3.7 \%) \\
1 \\
4 \\
-\end{array}$ & . & $\begin{array}{c}7(10 \%) \\
2 \\
2 \\
3\end{array}$ \\
\hline
\end{tabular}

Table 1: Histology outcomes by patients' characteristics (+: positive, -: negative, A: antrum, C: corpus).

\begin{tabular}{|c|c|c|c|c|c|}
\hline Sites - based biopsy & Score (Variables) & Activity & Mononuclear inflammation & Metaplasia & Atrophy \\
\hline \multirow{4}{*}{ Corpus } & $\operatorname{Normal}(0)$ & 128 & 170 & 321 & 289 \\
\hline & Mild (1) & 104 & 74 & 7 & 31 \\
\hline & Moderate (2) & 64 & 54 & 0 & 7 \\
\hline & Severe (3) & 32 & 30 & 0 & 1 \\
\hline \multicolumn{2}{|l|}{ Total } & 328 & 328 & 328 & 328 \\
\hline \multirow{4}{*}{ Antrum } & $\operatorname{Normal}(0)$ & 150 & 182 & 315 & 232 \\
\hline & Mild(1) & 86 & 84 & 7 & 69 \\
\hline & Moderate (2) & 66 & 44 & 6 & 27 \\
\hline & Severe (3) & 26 & 38 & 0 & 5 \\
\hline \multicolumn{2}{|l|}{ Total } & 328 & 328 & 328 & 328 \\
\hline
\end{tabular}

Table 2: Histopathological classification of submitted biopsies according to Sydney system.

\section{Discussion}

In the clinical setting, it is desirable to find a rapid and cost-effective method for detection of $H$. pylori. There are many methods for detection of $H$. pylori infection [17]. Endoscopic mucosal biopsy and histopathology are considered as valuable diagnostic tools for $H$. pylori detection. As well as, it provides a proper evaluation of gastric mucosal changes that have been attributed to chronic $H$. pylori infection i.e. glandular atrophy and/or intestinal metaplasia. It is still widely used as a main diagnostic method in suspicious patients with upper gastrointestinal symptoms or in highly prevalent areas [7]. We reported in our study that $193(58.8 \%)$ have been detected to have $H$. pylori, 111 (38.8\%) patients, both antral and corpus biopsies were identified positive for $H$. pylori. Totally $30.8 \%$ of our patients had atrophy in the antrum and/or corpus or both. Intestinal metaplasia was identified in $17(5.2 \%)$ patients.
There is always a debate about the best location of gastric mucosal biopsy that can yield more sensitive detection of $H$. pylori especially in presence of atrophic gastritis [18]. In our work; we found that the frequency of $H$. pylori detection in case of gastritis without atrophy or metaplasia was higher with additional corpus biopsy compared with only antrum-based biopsy.

\section{Conclusion}

H. pylori associated atrophic gastritis decreases sensitivity of detection rates of $H$. pylori. Atrophic changes are predominantly affect antrum first. Adding corpus biopsy to the routine antrum biopsy during endoscopy is recommended for proper evaluation of $H$. pylori infection case of gastric atrophy and to avoid false negative diagnosis. 


\section{References}

1. Marshall BJ, Warren JR (June 1983). "Unidentified curved bacilli on gastric epithelium in active chronic gastritis". The Lancet. 321 (8336): 1273-5. doi:10.1016/S0140-6736(83)92719-8. PMID 6134060 .

2. Marshall BJ, Warren JR (June 1984). "Unidentified curved bacilli in the stomach of patients with gastritis and peptic ulceration". The Lancet. 323 (8390): 1311-5. doi:10.1016/S01406736(84)91816-6. PMID 6145023.

3. Sweet, Melissa (2 August 1997). "Smug as a bug". The Sydney Morning Herald. Retrieved 28 January 2007.

4. Blaser MJ (2006). "Who are we? Indigenous microbes and the ecology of human diseases" (PDF). EMBO Reports. 7 (10): 95660. doi:10.1038/sj.embor.7400812. PMC 1618379. PMID 17016449.

5. Yamaoka, Yoshio (2008). Helicobacter pylori: Molecular Genetics and Cellular Biology. Caister Academic Pr. ISBN 1904455-31-X.

6. Bytzer P, Dahlerup JF, Eriksen JR, Jarbøl DE, Rosenstock S, Wildt S (April 2011). "Diagnosis and treatment of Helicobacter pylori infection". Dan Med Bull. 58 (4): C4271. PMID 21466771. Archived from the original on 5 January 2014. Retrieved 7 August 2013.

7. Butcher 2003, pp. 24-5

8. Ryan, Kenneth (2010). Sherris Medical Microbiology. McGrawHill. pp. 573, 576. ISBN 978-0-07-160402-4.

9. Ito M, Haruma K, Kamada T, Mihara M, Kim S, Kitadai Y, et al. Helicobacter pylori eradication therapy improves atrophic gastritis and intestinal metaplasia: a 5-year prospective study of patients with atrophic gastritis. Aliment Pharmacol Ther. 2002;16:1449-1456.

10. Chey WD, Wong BC. American College of Gastroenterology guideline on the management of Helicobacter pylori infection. Am J Gastroenterol. 2007;102:1808-1825.

11. Gisbert JP, Pajares JM. Stool antigen test for the diagnosis of Helicobacter pylori infection: a systematic review. Helicobacter. 2004;9:347-368.

12. 1Elvira Garza-González, Guillermo Ignacio Perez-Perez, HéctorJesús Maldonado-Garza, Francisco Javier Bosques-Padilla. A review of Helicobacter pylori diagnosis, treatment, and methods to detect eradication. World $\mathrm{J}$ Gastroenterol. 2014;20(6):1438-1449.

13. Aydin O, Egilmez R, Karabacak T, Kanik A. Interobserver variation in histopathological assessment of Helicobacter pylori gastritis. World J Gastroenterol. 2003;9(10):2232-5.

14. Fallone CA, Loo VG, Lough J, Barkun AN. Hematoxylin and eosin staining of gastric tissue for the detection of Helicobacter pylori. Helicobacter. 1997;2(1):32-5.

15. Laine L, Lewin DN, Naritoku W, Cohen H. Prospective comparison of H\&E, Giemsa, and Genta stains for the diagnosis of Helicobacter pylori. Gastrointest Endosc. 1997;45(6):463-7.

16. Uemura N, Mukai T, Okamoto S, Yamaguchi S, Mashiba H, Taniyama K, et al. Effect of Helicobacter pylori eradication on subsequent development of cancer after endoscopic resection of early gastric cancer. Cancer Epidemiol Biomarkers Prev. 1997;6(8):639-42.

17. Malfertheiner P, Megraud F, O'Morain C, Bazzoli F, El-Omar E, Graham D, et al. Current concepts in the management of Helicobacter pylori infection: the Maastricht III Consensus Report. Gut. 2007;56(6):772-81.
18. Kokkola A, Kosunen TU, Puolakkainen P, Sipponen P, Harkonen M, Laxen F, et al. Spontaneous disappearance of Helicobacter pyloriantibodies in patients with advanced atrophic corpus gastritis. APMIS. 2003;111(6):619-24.

19. Dixon MF, Genta RM, Yardley JH, Correa P. Classification and grading of gastritis. The updated Sydney system. International workshop on the histopathology of gastritis, Houston 1994. Am J Surg Pathol. 1996;20(10):1161-81.

20. Sudraba A, Daugule I, Rudzite D, Funka K, Tolmanis I, Engstrand L, et al. Performance of Routine Helicobacter pylori Tests in Patients with Atrophic Gastritis. J Gastrointestin Liver Dis. 2011;20(4):34954.

21. Tonkic A, Tonkic M, Lehours P, Mégraud F. Epidemiology and diagnosis of Helicobacter pylori infection. Helicobacter. 2012;17 Suppl 1:1-8. doi: 10.1111/j.1523-5378.2012.00975.x.

22. Arismendi-Morillo G, Hernández I, Mengual E, Abreu N, Molero N, Fuenmayor A, et al. Gastric cancer risk estimate in patients with chronic gastritis associated with Helicobacter pylori infection in a clinical setting. Rev Gastroenterol Mex. 2013;78(3):135-43. doi: 10.1016/j.rgmx.2013.01.004. Spanish.

23. Hazell SL, Hennessy WB, Borody TJ, Carrick J, Ralston M, Brady L, et al. Campylobacter pyloridis gastritis II: Distribution of bacteria and associated inflammation in the gastroduodenal environment. Am J Gastroenterol. 1987;82(4):297-301.

24. Dursun M, Yilmaz S, Yükselen V, Kilinç N, Canoruç F, Tuzcu A. Evaluation of optimal gastric biopsy site and numbers for H. pylori, gastric atrophy. Hepatogastroenterology. 2004;51(60):1732-5.

25. Genta RM, Graham DY. Comparison of biopsy sites for the histopathologic diagnosis of Helicobacter pylori: a topographic study of $\mathrm{H}$. pylori density and distribution. Gastrointest Endosc. 1994;40(3):342-5.

26. Kim CG, Choi IJ, Lee JY, Cho SJ, Nam BH, Kook MC, et al. Biopsy site for detecting Helicobacter pylori infection in patients with gastric cancer. J Gastroenterol Hepatol. 2009;24(3):469-74. doi: 10.1111/j.1440-1746.2008.05679.x.

27. Kang HY, Kim N, Park YS, Hwang JH, Kim JW, Jeong SH, et al. Progression of atrophic gastritis and intestinal metaplasia drives Helicobacter pylori out of the gastric mucosa. Dig Dis Sci. 2006;51(12):2310-5.

28. Satoh K, Kimura K, Takimoto T, Kihira K. A follow up study of atrophic gastritis and intestinal metaplasia after eradication of Helicobacter pylori. Helicobacter. 1998;3(4):236-40.

29. Yoo JY, Kim N, Park YS, Hwang JH, Kim JW, Jeong SH, et al. Detection rate of Helicobacter pylori against a background of atrophic gastritis and/or intestinal metaplasia. J Clin Gastroenterol. 2007;41(8):751-5.

30. Lan HC, Chen TS, Li AF, Chang FY, Lin HC, et al. Additional corpus biopsy enhances the detection of Helicobacter pylori infection in a background of gastritis with atrophy. BMC Gastroenterol. 2012;12:182. doi: 10.1186/1471-230X-12-182. 